\title{
Thromboembolic Conditions, Aetiology Diagnosis and Treatment in Dogs and Cats
}

\author{
Filip Konečný1 ${ }^{1,2}$ \\ ${ }^{1}$ University of Veterinary Medicine and Pharmaceutical Sciences, Faculty of Veterinary Medicine, \\ Department of Physiology and Pathophysiology, Brno, Czech Republic \\ ${ }^{2}$ St. Joseph Hospital and McMaster University, Ontario, Canada
}

Received April 1, 2009

Accepted March 8, 2010

\begin{abstract}
In veterinary medicine, thrombo-embolism (TE) is an under-appreciated medical condition that requires immediate recognition. Since TE is multifactorial and its mode of presentation may vary, veterinarians face great difficulties in making a definitive diagnosis in a timely manner. In addition, most of the underlying conditions that give rise to TE are life-threatening and an aggressive diagnostic and therapeutic approach is required. Not only does the diagnosis and treatment of this condition require the collaboration of many specialties, the costs of therapy can be excessive with a high risk of recurrence. As such, owners have to be thoroughly informed before the therapy commences. While TE has been well-characterized in humans and is associated with significant morbidity and mortality, little information of similar quality is available in veterinary medicine. In addition, TE in animals is distinct from its human counterpart and we cannot simply adapt what is known from human clinical trials. With the promise of improvements in imaging modalities that improve our diagnostic capabilities, the window of opportunity to treat TE increases. This article focuses on aetiology, clinical presentation, diagnosis, and treatment of dogs and cats affected by TE.
\end{abstract}

Prothrombotic conditions, non-pulsatile blood flow, endothelial damage, hypercoagulability, clinical presentation

Thrombo-embolism (TE) in animal patients (canine and feline) can occur at various anatomical locations, including pulmonary vessels, portal vein, vena cava, aortic trifurcation, heart, renal and cerebral arteries, intestinal and mesenteric vessels, spleen, iliac, femoral, coronary and brachial arteries, femoral vein, and vessels of the microcirculation (Butler 1971; Liu et al. 1986; Klein et al. 1989; LaRue and Murtaugh 1990; Laste et al. 1992; Van Winkle and Bruce 1993; Van Winkle et al. 1993; Rawlings et al. 1993; Sottiaux and Franck 1998; Palmer et al. 1998; Driehuys et al. 1998; Sottiaux and Franck 1999; Diaz Espineira 1999; Bateman et al. 1999; Norris et al. 1999; Boswood et al. 2000; Tsujino et al. 2005; Gonçalves et al. 2008). The clinical effects of thrombo-embolism depend mainly on the size and site of the final destination of the thrombus/embolus.

It is commonly accepted that arterial thrombi are composed predominantly of platelets as compared to fibrin. This is in contrast to vein thrombi, where platelets are scarce and there are larger amounts of cross-linked fibrin. Arterial clots are also generally firmly attached to the underlying vessel wall. In this setting, clot dislodgement will sometimes occur, causing re-canalization of the vessel with relief of the obstruction, but the threat of embolism distally remains. In contrast, venous thrombi are mainly associated with lower limb deep vein thrombosis (DVT) in humans. DVT, however, is not common in veterinary patients. This is thought to be due to the differences in the epigenetics, platelet structure, vascular anatomy and physiological non-bipedal circulation. In fact, venous thrombi tend to be occlusive with resulting blood stagnation and long obstructive casts that are generally firmly attached to the underlying vessel wall.

Unfortunately, there is a lack of information available with regard to the basic mechanisms underlying TE in cats and dogs, resulting in knowledge gaps in the understanding of: (1) the composition of the arterial/venous clots, (2) endogenous vascular thrombolytic and

Address for correspondence:

Dr. Filip Konečný

Department of Physiology, Faculty of Veterinary Medicine

University of Veterinary and Pharmaceutical Sciences Brno

Palackého 1-3, 61242 Brno, Czech Republic

Phone + 420541562301

E-mail: filkon@canada.com

http://www.vfu.cz/acta-vet/actavet.htm 
anticoagulant capacity and (3) thrombus-endothelial vessel interactions and flow conditions (Konecny 2007b, Konecny 2008).

\section{Prothrombotic factors}

It was accepted for long time that factors that impair circulation increase the risk of prothrombotic conditions in the veterinary patient. This concept was first introduced by Virchow as part of his triad in 1856 . Common prothrombotic conditions in veterinary medicine include sepsis, neoplasia, heartworm disease, trauma, heart disease, hyperadrenocorticism, immune-mediated haemolytic anaemia, and protein-losing nephropathy (Schaub and Rawlings 1980; Klein et al. 1989; Nichols 1990; Fox 1998; Kittleson 1998; Sottiaux and Franck 1998; Palmer et al. 1998; Jaffe et al. 1999; Littman et al. 2000; Thompson et al. 2004; Konecny 2006a). As more is learned about the development and pathophysiology of TE, additional disorders with pro-thrombotic tendencies are being reported. Veterinary clinicians should have more knowledge of the causal factors of this condition.

\section{Non-pulsatile flow}

In humans, the risk of vein thrombosis during prolonged rest in bed was first established in the late $19^{\text {th }}$ century by Malpother (1880). Observation of reduced venous blood velocity in recumbent limbs helped to explain this phenomenon (McCartney and Owre 1920; McCartney 1920; Owre 1927; Wright et al. 1952; Wright 1952). Later it became clear that retarded flow is not the same as non-pulsatile flow. In addition, pulsatility and mean blood linear velocity inside the vessel lumen are not necessarily coupled. In fact, rapid or intense muscular contraction which enhances pulsatility can actually decrease the mean linear velocity. This inverse relationship can help us to understand the imperfectly used term 'stasis of the blood' in Virchow's triad (Schina et al. 1993). Prolonged post-surgery rest in bed slows down the venous return, in addition to a decrease of blood pulsatility.

Reports of reduced venous blood flow conditions as measured by venous occlusion plethysmography are rare in veterinary medicine. Low leg venous pulsatile blood flow increases a patient's predisposition toward thrombosis.

Heart disease is often associated with poor venous return. In veterinary medicine, heart disease is seen most frequently in feline patients with predominantly enlarged left atria (LA) caused by hypertrophic, restrictive or dilated cardiomyopathy (Schober and Maerz 2006, Bédard et al. 2007, Brazzell et al. 2007, Stokol et al. 2008, and Jandrey et al. 2008). Only Bédard et al. (2007) looked further with the use of echocardiography; however, no additional findings were reported. Therefore, further studies are needed to assess: (1) the degree of endothelial dysfunction within the LA, (2) the flow pattern disturbance in the LV cavity and its possible influence on the aortic thrombo-embolism.

Numerous other diseases have also the potential to cause low pulsatile flow and thereby increase a patient's predisposition toward thrombosis. Examples of diseases that may potentially cause physical obstruction within the blood vessels include heartworms, intravenous catheters and invasive neoplastic masses that produce localized stasis in the affected area. Polycythaemia, leukaemia, thrombocytosis, diabetes and hyperglobulinaemia can all increase viscosity of blood, resistance to flow, stasis, and subsequent thrombotic tendencies (Konecny 2006b). Non-pulsatile blood flow can also occur with circulatory shock (Mitchell et al. 1999).

\section{Endothelial damage}

The balance between the prothrombotic and antithrombotic function is maintained by the endothelium. It is a specialized type of simple squamous epithelial tissue involved in vasoconstriction, vasodilatation, blood clotting, angiogenesis, inflammation and 
atherosclerosis. The endothelium helps to manage the vascular tone by secreting prostanoids, endothelium-derived relaxing factor (EDRF), endothelium-derived hyperpolarizing factor (EDHF), ATP, ADP, adenosine, and by regulating sodium and calcium fluxes. Local blood velocity and shear stress hypoxaemia can influence the secretion of these factors through changes in local blood velocity and through the activation of various signalling pathways in the endothelial cells themselves, despite their ability to tolerate anaerobic conditions. The endothelium is also a selective barrier between the vessel lumen and the surrounding tissue. Both direct trauma and secondary injury can result in pathologic endothelial dysfunction. As a result, the endothelial cells will swell and fragment. In addition, nuclear vacuolization, subendothelial oedema formation and detachment from the basement membrane can occur. There can also be the release of cellular mediators with the exposure of sub-endothelial proteins and activation of various cell signalling pathways. The activity of antithrombotic and anticoagulant factors, i.e. protein C (PC) and antithrombin III (ATIII), is also reduced. In addition, thrombomodulin, heparan sulphate, protein $\mathrm{S}$, and tissue factor pathway inhibitor (TFPI) are no longer produced and the synthesis of pro-thrombotic mediators, e.g. tissue factor (TF) and plasminogen activator inhibitor type 1 (PAI-1), is induced. These changes result in a significant pro-thrombotic risk.

The endothelial damage resulting from the parasite infection of the heartworm Dirofilaria immitis (DI) is very specific in veterinary medicine. The damage is limited to a small area and is highly prothrombotic. The damage starts as the adult parasite migrates and mechanically irritates the vascular intimal endothelial layer of pulmonary arterial walls. Intimal thickening, smooth muscle cell multiplication and villous formation leading to increased vascular permeability and perivascular oedema (Schaub and Rawlings 1980) has been observed. Pathogenesis of the prothrombotic nature of the heartworm infection has generally been attributed to either physical obstruction by the adult parasites, the host's immune response to adult parasites, or microfilariae. When adulticidal therapy is employed, it causes death, fragmentation and embolization of the heartworm fragments. Changes in vascular reactivity in the pulmonary artery from heartworm-infected dogs are, in many cases, attributed to endothelial cell damage and vascular smooth muscle hyperplasia (Schaub et al. 1981; Rawlings et al. 1985). The smooth muscle cells within the vessel wall are thought to be the primary target of the parasite and therefore this should influence the treatment options. In contrast, other authors described that the endothelial cell is a more likely target of the parasite, since the heartworm infection does not influence the vascular tone of the pulmonary artery. Dirofilaria immitis (DI) infection does not cause a complete depression of endothelial cell function, but rather selectively alters endothelial cell behaviour (Mupanomunda et al. 1997). Moreover, when the vascular endothelium is exposed to higher doses of the DI antigen with subsequent adulticide treatment, there is an increased expression of enzymes responsible for the synthesis of NO, eNOS and iNOS and the increased synthesis of the eicosanoids related to inflammation such as COX-2, 5-LO, PGE2 and LTB4 (Morchón et al. 2008). The expression of adhesion molecules ICAM-1 and PECAM-1 is also augmented. Dirofilarial antigen further decreases the endothelial cell permeability.

Intravenous (i.v.) catheters lead to thrombosis in veterinary patients. Site specific injury of the vessel intima, endothelial cell denudation, myointimal hyperplasia near the catheter tip with villous papillary projections and deposition of extracellular matrix (similar to the intimal changes seen in DI) has been observed (Mesfin et al. 1988). Thrombotic complications are thought to be directly related to the position, size and type of prothrombogenic material of the catheter, as well as it placement time-duration. Biologically inert catheters (i.e. polyurethane) with an anti-thrombotic coating, used for short time and non-disruptive to the vasculature, are least associated with thrombus formation ( $\mathrm{Du}$ et al. 2007). When highly anticoagulant covalent antithrombin-heparin complex (ATH) was 
applied on the inner surface of the permanent catheters, the higher amount of altered forms of fibrinogen was detected, supporting its higher antithrombotic activity compared to only heparin coating ( $\mathrm{Du}$ et al. 2007).

Atherosclerosis leads primarily to thickening of the arterial wall in dogs, secondary to depositions of lipid and cholesterol that cause disruption of the tunica intima with extension to the tunica media and tunica adventitia (Kagawa et al. 1998). Lesions can be found in the aorta and muscular arteries in many organs, i.e. heart, eyes, spleen, kidneys, lungs, pancreas, alimentary tract, urogenital organs, prostate and urinary bladder. Direct immunohistochemistry staining identified lipids containing low density lipoprotein (Kagawa et al. 1998). Three dog breeds, Miniature schnauzer, Doberman pinscher, and Labrador retriever, were identified as most frequently affected (Liu et al. 1986). Deprived tissue perfusion, ischemia, and reperfusion injury with oxygen-free radical production leads to ischemic heart disease (Falk and Jönsson 2000). About half of the dogs die suddenly while the others develop acute or chronic congestive heart failure. Both electrocardiography (ECG) and echocardiography identified changes of cardiac function with decreased myocardial contractility, atrial fibrillation and sinus tachycardia being the most common (Falk and Jönsson 2000).

\section{Hypercoagulability}

There exists a balance of activators and inhibitors of the coagulation system in healthy animals. In disease states, this balance is disrupted and favours pro-coagulation. Major inhibitors of coagulation such as antithrombin III (AT III), tissue factor pathway inhibitor (TFPI), protein S and C (PS, PC) when inhibited, provide a pro-coagulant milieu. The hypercoagulability risk can be directly linked to alterations in blood coagulability and commonly results in pro-thrombotic tendencies in veterinary patients. In contrast to humans, the usage of markers of activated coagulation in veterinary patients is not very useful as indicators of increased thrombotic risk. Factors that reflect hyper-coagulable states in veterinary patients include decreased levels of ATIII (Bédard et al. 2007), thrombin-antithrombin complex (TAT) (Bédard et al. 2007, Stockol et al. 2008), PC and PS, plasminogen, and tissue plasminogen activator (t-PA); increased levels of PAI-1; and increased platelet aggregation (Lunsford and Mackin 2007).

The role of the fibrinolytic system in the pathogenesis of hyper-coagulability has been addressed and partially recognized in human medicine (Lunsford and Mackin 2007). The presence of TAT complex is a good indicator of thrombin generation in vivo and is a sensitive marker of hypercoagulation. In plasma, thrombin is activated and rapidly inactivated by AT III, followed by elimination from the circulation. In hypercoagulable states in dogs with malignant tumours (Maruyama et al. 2005), hyperadrenocorticism (Jacoby et al. 2001) or in cats with cardiomyopathy (Bédard et al. 2007, Stockol et al. 2008) the significance of procoagulation factors (e.g. II, V, VII, IX, X, XII) and fibrinogen play a role in active sub-clinical thrombosis (Konecny 2007b). Subsequently, thrombin is found on platelets and other extra-vascular cells in bloodstream. Thrombin at this stage is able to activate factor XI to initiate a feedback mechanism that would lead to a further increase of its production, while enhancing platelet activation and haemostatic plug formation. As thrombin converts fibrinogen to fibrin, it helps to incorporate platelets and other circulating cells into a thrombus. Thrombin at this stage activates platelets to form loose platelet plugs. They bind to newly formed collagen while releasing adenosine 5 diphosphate (ADP), thromboxane (TXA 2), serotonin phospholipids and lipoproteins, and become more rigid and fibrinolysis-resistant.

Metabolic diseases, such as protein-losing nephropathy (PLN), may increase the presence 
of hypercoagulable factors in blood, especially TXA 2 and fibrinogen (Littman et al. 2000, Lunsford and Mackin 2007). Proteinuria leads to hypoalbuminaemia hypercholesterolaemia and polycythaemia, which is the basis for decreasing of the plasma volume, thereby generating platelet-platelet contact and hyper-aggregability. In addition, hypertension can lead to glomerular disease and therefore a loss of ATIII. In case of protein-losing enteropathies (PLE), extravasation of larger proteins takes place. Protein loss, however, leads less frequently to an increase in TE risk because of the larger molecular size of the coagulation factors as compared to ATIII.

Hypercoagulability has also been implicated in a number of other veterinary diseases with a prothrombotic risk. Diabetes mellitus (DM) can result in platelet dysfunction and hyperaggregability. Decreased vascular synthesis and sensitivity to prostacyclin (PGI-2) and decreased synthesis of NO by vascular EC, coupled with increased production of TXA 2, leads directly to TE. Hyperglycaemia in DM inhibits NO production, blocking eNOS and increasing production of reactive oxygen species (ROS). In addition, hyperglycaemia increases production of various adhesion molecules, inflammatory cytokines, cellular transcription factors and decrease levels of the naturally occurring anti-fibrinolytic factors such as PAI-1. Further activation of monocytes and changes of EC leads to increasing activity of tissue factor (TF).

Hypercoagulability in neoplasia occurs frequently in veterinary medicine. Due to the multifactorial nature of the hyper-coagulability in oncology cases, veterinary clinicians have a tendency to combine the measurements of routine coagulation indicators such as activated partial thromboplastin time (aPTT), prothrombin time (PT), platelet count, and D-dimer concentration with the thromboelastography TEG (Kristensen et al. 2008; Wiinberg et al. 2009). This well-established method developed in 1948 measures speed and strength of clot formation from whole blood. TEG can serve as an overall test of haemostatic function in veterinary oncology by its in vitro ability to assess the coagulability of plasma, i.e. levels of TF, platelet function, and fibrinolysis. The patterns of change in strength and elasticity within the clot help to characterize the overall coagulability, in the absence of EC interactions. This is important in consideration of the hyperaggregability of platelets in numerous tumours and TF that can be released by neoplastic cells thereby leading to the activation of the coagulation cascade.

\section{Clinical status}

Clinical cases of TE in veterinary medicine are fairly analogous to human TE, with several differences. There are differences in the degree of functional collateral circulation which aid in development of complications such as limb necrosis. Some of the clinical signs include: decreased neuromuscular function, self-mutilation, an abdominal pain, hyperkalaemia, dramatic increases of muscular creatine kinase, and liver enzymes. The ability to correctly identify the clinical presentation of TE seems to be directly related to sudden decompensation of organ function, as it is observed in pulmonary thromboembolism (PTE), cranial vena cava thrombosis (CVCT), aortic thrombo-embolism (ATE), coronary artery thromboembolism (CATE), portal vein thrombosis (PVT). Based on the clinical status, radiographic assessment is now being replaced by non-invasive imaging modalities and techniques such as echocardiography with colour Doppler flow imaging and ventilation-perfusion scans that are adapted to small animal. While non-invasive techniques hold great promise for the future diagnosis of TE, they are restricted to selected reference institutions.

\section{Types of thromboembolism Pulmonary thromboembolism (PTE)}

Pulmonary thromboembolism refers to the obstruction of the pulmonary vasculature by a thrombus or multiple thrombo-emboli. Structural compositions of thrombo-emboli vary, and in most cases can be linked to factors such as thrombus age, its cross-linked stage and site of thrombus development and expansion. Heart mechanical mincing action by 
papillary muscles and valves occurring while the thrombus passes through the heart and is finally expulsed into the pulmonary artery, has to be considered (Konecny 2006c). Initially, its structure might be different if the embolic source is a thrombus created in a popliteal or femoral arterial source, after disruption of an atherosclerotic lesion, or formed while passing through multiple valves of heart and orifices in venous vasculature.

Clinical signs of PTE vary and in many cases the success of treatment depends on the clinical skills of veterinarian and the percentage of affected lung vasculature. A plethora of diseases depend on the origin of PTE in animals. In dogs, PTE can be the result of diseases such as heartworm disease Dirofilaria immitis, Leishmaniasis, fungal infection by Blastomyces dermatitidis, bacterial disease, sepsis, DIC, immune-mediated haemolytic anaemia (IMHA), neoplasia, hyperadrenocorticism, pancreatitis, nephrotic syndrome, cardiovascular diseases, and hypothyroidism (McCartney 1927; LaRue and Murtaugh 1990; Nichols 1990; Rawlings et al. 1993; Klein et al. 1989; Kittleson et al. 1998; Ware and Fenner 1998; Norris et al. 1999; Johnson et al. 1999; McGuire et al. 2002). In cats, PTE is the result of cardiomyopathies, neoplasia, IMHA sepsis Protein-losing nephropathy PLN or Protein-losing enteropathy PLE (Norris et al. 1999; Sottiaux and Franck 1999). Recently, Schermerhorn identified neoplasia, anaemia of unidentified cause, and pancreatitis as a strong diseases factor in association with PTE in cats (Schermerhorn et al. 2004).

\section{Cranial vena cava thrombosis (CVCT)}

Cranial vena cava thrombosis development is linked to several conditions in dogs and cats including neoplasia, jugular catheter placement, heart disease, IMHA, thrombocytopenia, sepsis and glomerulopathy (Palmer et al. 1998; Sottiaux and Franck 1998). In addition, position placement of a central venous catheter is strongly correlated with CVCT, mostly those longer indwelling (Forauer et al. 2006).

\section{Aortic thrombo-embolism (ATE)}

Aortic thrombo-embolism in both cats and dogs is an uncommon condition that usually arises secondarily to a complicating illness. In dogs, aortic and iliac thrombosis is associated with neoplasia, renal disease, cardiac dysfunction, gastric dilation and volvulus, hypothyroidism and hyperadrenocorticism (Carter et al. 1990; Laste and Harpster 1992; Van Winkle et al. 1993; Boswood et al. 2000; Santamarina et al. 2003; MacGregor et al. 2004; Tsujino et al. 2005). Arterial thromboembolism has also been associated with blastomycosis (Ware and Fenner 1998).

Aortic thrombo-embolism in cats is a consequence of several diseases i.e. hyperthyroidism, cardiomyopathies, and neoplasia (Laste and Harpster 1992). In a study by Smith et al. (2003), a total of 127 cats with ATE, 87 were treated for acute limb ATE, of which $39(45 \%)$ survived. In the left atrial appendage (LAA) of cats, the intracardiac necrotic endomyocardial patches were recognized on necropsies to create niches of pro-coagulation. Thrombi later broke off and were lodged within the narrowing of the aorta (Smith et al. 2003). Schober and Maerz predicted, based on the Doppler echocardiographies of cat's LAA, that the natural (smoke-like) contrast created by blood flow with localized blood stasis led to the thrombus formation (Schober and Maerz 2006).

\section{Coronary artery thrombo-embolism (CATE)}

Coronary artery thrombo-embolism in dog and cat leads to myocardial infarction (MI). Ninety-seven percent of dogs present CATE localized in the left ventricle (LV). Infarctions in cats are found in all parts of the myocardium including the right and left ventricle and 
the interventricular septum (IVS) (Driehuys et al. 1998). In dog, CATE was found in the subsinuosal interventricular branch of the coronary artery composed of mostly platelets and fibrin with the same histology characteristics as those of the mural thrombi of the leftatrial endocardium. Dislodgement of part of the mural thrombus (i) might have caused TE of the subsinuosal interventricular branch (Seki et al. 1998).

\section{Portal vein thrombosis (PVT)}

Clinical-pathological description of portal vein thrombosis (PVT) in cats is difficult because of other diseases are associated with PVT, which includes e.g. hepatitis, pancreatitis, peritonitis, neoplasia, and congenital portosystemic shunt (Rogers et al. 2008). In dogs, a similar situation is reported whereby portal thrombi extend into the mesenteric veins causing infarction of the jejunum. Localized inflammation and particularly hepatitis and porto-systemic shunt are reported as one of the major risk factor in both species (Van Winkle and Bruce 1993; Diaz Espineira et al. 1999; Bressler et al. 2003; Rogers et al. 2008).

\section{Treatment}

In most cases, treatment depends on the disease pathophysiology, clinical ability and diagnostic skills of the emergency veterinary team and the owner's financial situation. General therapy of TE is directed towards general patient support, maintaining hydration, heart rate and rhythm control, electrolyte balance, correction of hypothermia, and close monitoring of limb viability with prevention of self-destructive mutilation. Adjunctive therapies limit thrombus formation and growth. Biochemical evaluations are useful to assess basic coagulation profiles (aPTT, PTT and platelet count) renal function (BUN/ creatinine), and electrolyte levels. Epidural analgesia with morphine $(0.05$ to $0.1 \mathrm{mg} / \mathrm{kg}$ one time) can be safe and effective when administered within the first 12 to $18 \mathrm{~h}$ after embolization. ECG monitoring of hospitalized animals with TE might be a competent technique to detect large increases in serum potassium concentration (widening of the QRS complex, increasing $\mathrm{T}$-wave amplitude, prolongation of P-R interval). Acute TE cases require emergency surgical interventions. In veterinary medicine emergency surgical thrombo-embolectomy is rarely performed mainly due to the high risk of the procedure (anaesthesia, arrhythmia, hypothermia, DIC), as well as the lack of appropriate equipment and adequately trained personnel in the regular clinical/office setting. To combine direct surgical thrombo-embolectomy with thrombolytic therapy, the clinician must be experienced. To use plasminogen activators (PA) such as streptokinase, urokinase, and tissue (t-PA) or recombinant tissue (rt-PA) as well as other less recognized PA i.e. single chain urokinase plasminogen activator (scuPA) and anisoylated plasminogen-streptokinase activator complex (APSAC), the clinician must be aware of the different modes of its action, the haemorrhagic side effects, the cost and the lack of protocols for their administration (Thompson et al. 2001; Bliss et al. 2002; Konecny 2008). Streptokinase and (or) urokinase generate non-specific proteolytic enzyme plasmin through conversion from its proenzyme plasminogen. This causes a generalized lytic state, with the incipient hazard of bleeding in many organs (Moore et al. 2000; Konecny 2008 a). Streptokinase was studied in 15 cats with ATE. Loading dose of $90,000 \mathrm{IU} /$ cat over 20 to $30 \mathrm{~min}$, followed by a constant-rate infusion $45,000 \mathrm{IU} / \mathrm{h}$ for $3 \mathrm{~h}$ produced systemic fibrinolysis with no detectable adverse effects, but it failed to produce significant improvement as measured by venous angiograms, thermal circulatory indexes, or significant reduction in mean thrombus weight (Killingsworth et al. 1986). The treatment application of tissue of human recombinant tissue PA's in dogs and cats is limited as for the associated cost, dubious reperfusion rates, adverse effects i.e. bleeding into cavities, hyperkalaemia due to reperfusion syndrome, heart failure, sudden death (Konecny 2008a) and mostly due to lack of effective veterinary based protocols. 
Various non-acute cases can be managed by vasoactive chemicals i.e. hydralazine or acepromazine maleate to support arterial vasodilation. The non-steroidal anti-inflammatory drugs can be administered for myalgia associated with ischemic myopathy, in addition to blocking platelet aggregation and activation. Platelet aggregation can be controlled with clopidogrel at dose 18.75 to $75 \mathrm{mg}$ p.o, every $24 \mathrm{~h}$ in cats (Hogan et al. 2004). Irreversibly inactivated cycloxygenase by acetylsalicylic acid (Aspirin), an enzyme critical for converting arachidonic acid to TXA-2, induces a functional defect in platelets. There is still lack of large veterinary clinical trials to demonstrate the anti-platelet properties of Aspirin in the feline patient. Aspirin-induced acetylation of the cyclooxygenase is irreversible and persists for about 7 to 10 days (approximately the life-span of a thrombocyte). In the late 90's, limited reports of platelet-vessel wall interactions after $D$. immitis damage was described by Rawlings et al. (1985). In their report, dogs treated with Aspirin had less complex vascular lesions with smaller surface areas as compared to the control group. Other platelet inhibitors function differently: (1) glycoprotein IIa/IIIb receptor blockers (Abciximab, Eptifibatide, Tirofiban), (2) ADP-binding inhibitors (i.e. Clopidogrel), (3) calcium channel blockers (Nicardipine, Nifedipine, Pranidipidine etc.), and (4) phosphodiesterase inhibitors (non-selective and selective). These drugs have been predominantly effective in humans. For use in veterinary medicine it would be necessary to establish their importance, efficacy and dosage required in the treatment of TE.

Anticoagulant therapy in veterinary medicine utilizes two primary preventive strategies (1) heparins (unfractionated heparin sodium-UFH and low-molecular weight heparinsLMWH) and (2) warfarin (coumarin). These medications have not been tested in a large veterinary clinical trials and the reported dosages vary. Both have an effect on formed thrombi and act to prevent further thrombus growth. Heparin acts through its cofactor binding to lysine sites on plasma antithrombin, to neutralize thrombin and the binding of other activated serine proteases (factors XII, XI, X, and IX). About one third of administered heparin binds to AT III, and this fraction is responsible for the majority of its anticoagulant effect. The dose varies because of its bleeding side effects. UFH dose should be based on aPTT, PT, and plasma anit-Xa activity determined in serial blood samples. It may be administered as an initial i.v. dose (100 to $200 \mathrm{IU} / \mathrm{kg}$ ), then 50 to 100 IU $/ \mathrm{kg}$ s.c.q6-8h then adjusted to prolong aPTT to about one and a half to two times of the pre-treatment values (Diquélou et al. 2005). LMWH has potential benefit in cats at risk for ATE disease. The advantages of use of LMWH over UFH in cats include less intensive monitoring and frequency of administration with lower bleeding episodes. However, LMWH pharmacokinetics in veterinary patients have not been properly tested in a large number of patients. Recently, $250 \mathrm{IU} / \mathrm{kg}$ q6h of Dalteparin, and $100 \mathrm{IU} / \mathrm{kg}$ q12h of Enoxaparin, $1 \mathrm{mg} / \mathrm{kg} \mathrm{q} 12 \mathrm{~h}$ have been tested in a cross-over study in 4 cats treated for the prevention of TE (Alwood et al. 2007).

Warfarin is a synthetic derivative of coumarin, a chemical found naturally in many plants. Warfarin and related coumarins decrease blood coagulation by inhibiting vitamin $\mathrm{K}$ epoxide reductase. This enzyme recycles oxidated vitamin $\mathrm{K}$ to its reduced form after it has participated in the carboxylation of several blood coagulation proteins and coagulation factors II, VII, IX, and X. For this reason, drugs in this class are also referred to as vitamin $\mathrm{K}$ antagonists. Their use is based on the assumption that by slowing down clotting factor synthesis or accelerating its inactivation, thrombosis can be prevented. In animals that have previously had a TE, oral anticoagulant therapy can decrease the risk of repetitive TE. Therapy should not be attempted without monitoring and appropriate patient selection, since each animal has a narrow therapeutic range of the steady-state concentration of total warfarin required to appropriately block prothrombin complex synthesis (Smith et al. 2000). The initial oral daily dosage in cats $(0.25$ to $0.5 \mathrm{mg} / \mathrm{cat})$ is adjusted to prolong PT to twice the normal value; alternatively, it is adjusted by the international normalization ratio 
(INR) to maintain a value between 2.0 to 3.0 (Smith et al. 2000). In humans, therapy with warfarin overlaps with UFH for several days since warfarin initially decreases protein C levels, faster than the coagulation factors, thus its anticoagulant function can paradoxically create a pro-thrombogenic state. Protein $\mathrm{C}$ is an innate anticoagulant that requires vitamin $\mathrm{K}$-dependent carboxylation for its activity. The necessity for this manoeuvre in cats has not yet been fully tested and established in small animal clinical practice.

In conclusion, it is critical to realize the importance of TE disease in veterinary medicine as an under-recognized medical condition with considerable consequences. Clinical trials of prevention and treatment of TE are limited and the lack of knowledge can not be always supplemented with data obtained from human clinical trials. In addition, it is important to realize that TE can be prevented by treating of primary disease i.e. cardiovascular, renal, hepatic, etc. Treatment of TE includes stabilization of the patient's condition, correction of hypothermia, reinstatement of blood flow, perfusion, pain management, and later prevention of pathologic thrombosis (and) or re-thrombosis. Although in many cases the underlying disease state is complex, minimizing the resulting vascular injury is critical. Optimization of tissue perfusion by use of the proper fluid therapy, management of relative balance of coagulation factors or avoiding prolonged blood stasis and total patient immobility should be used in order to support pulsatile blood flow. Antiplatelet and/or anticoagulant drug prophylaxis should not be used only in cases with high risk of TE but also in the prevention of re-thrombosis and/or in cardiomyopathies. Euthanasia is a reasonable alternative for animals suffering with acute TE, particularly if negative prognostic indicators are noted (Schermerhorn et al. 2004). It is beyond the scope of this article to follow all TE therapy and prevention interventions in-depth.

\section{Tromboembolické stavy, etiologie, diagnóza a léčba psa a kočky}

Thromboembolismus (TE) se ve veterinární medicíně řadí $\mathrm{k}$ špatně rozeznatelným klinickým stavům, proto je nutné mu věnovat okamžitou pozornost. Různorodost thromboembolismu staví veterináře před složitý úkol a to zejména, jak provést včasnou definitivní diagnózu. Většinu mnohdy skrytých přičin, dávajících možnost vzniku života-ohrožujícího TE, je nutno včas diagnostikovat a léčit. Diagnostika a léčba vyžaduje spolupráci mnoha odvětví a to radiologů, anesteziologů, kardiologů a chirurgů. Jelikož množství vynaložených finančních prostředků může být nadměrné, s riskem návratné trombózy, majitel pacienta musí být důkladně obeznámen s riziky před začátkem léčby. TE je velmi dobře charakterizován v humánní medicíně, doprovázen vysokou nemocností a úmrtností, ve veterinární medicíně však kvalitní informace chybí. Výsledky klinických studií humánní medicíny nemohou být jednoduše nahrazeny či být převzaty do medicíny veterinární. S rostoucí technologickou kvalitou zobrazovacích technik se diagnostické možnosti zlepšují a tedy i možnosti prodloužení včasného léčebného časového intervalu. Tento článek se zabývá příčinami, klinickou prezentací, diagnostikou a léčbou psa a kočky postižených TE.

\section{References}

Alwood AJ, Downend AB, Brooks MB, Slensky KA, Fox JA, Simpson SA, Waddell LS, Baumgardner JE, Otto CM 2007: Anticoagulant effects of low-molecular-weight heparins in healthy cats. J Vet Intern Med 21: 378-87

Bateman SW, Mathews KA, Abrams-Ogg AC, Lumsden JH, Johnstone IB, Hillers TK, Foster RA 1999: Diagnosis of disseminated intravascular coagulation in dogs admitted to an intensive care unit. JAVMA 215: 798-804

Bedard C, Lanevschi-Pietersma A, Dunn M 2007: Evaluation of coagulation markers in the plasma of healthy cats and cats with asymptomatic hypertrophic cardiomyopathy. Vet Clin Pathol 36: 167-72

Bliss SP, Bliss SK, Harvey HJ 2002: Use of recombinant tissue-plasminogen activator in a dog with chylothorax secondary to catheter-associated thrombosis of the cranial vena cava. J Am Anim Hosp Assoc 38: 431-5

Boswood A, Lamb CR, White RN 2000: Aortic and iliac thrombosis in six dogs. J Small Anim Pract 3: 109-14 
Brazzell JL, Borjesson DL 2007: Evaluation of plasma antithrombin activity and D-dimer concentration in populations of healthy cats, clinically ill cats, and cats with cardiomyopathy. Vet Clin Pathol 36: 79-84

Bressler C, Himes LC, Moreau RE 2003: Portal vein and aortic thromboses in a Siberian husky with ehrlichiosis and hypothyroidism. J Small Anim Pract 44: 408-10

Butler HC 1971: An investigation into the relationship of an aortic embolus to posterior paralysis in the cat. J Small Anim Pract $12: 141-158$

Carter WO 1990: Aortic thromboembolism as a complication of gastric dilatation/volvulus in a dog. J Am Vet Med Assoc 196: 1829-1830

Díaz Espiñeira MM, Vink-Nooteboom M, Van den Ingh TS, Rothuizen J 1999: Thrombosis of the portal vein in a miniature schnauzer. J Small Anim Pract 40: 540-543

Diquélou A, Barbaste C, Gabaig AM, Trumel C, Abella-Bourges N, Guelfi JF, Bousquet Mélou A 2005: Pharmacokinetics and pharmacodynamics of a therapeutic dose of unfractionated heparin $(200 \mathrm{U} / \mathrm{kg})$ administered subcutaneously or intravenously to healthy dogs. Vet Clin Pathol 34: 237-242

Driehuys S, Van Winkle TJ, Sammarco CD, Drobatz KJ 1998: Myocardial infarction in dogs and cats: 37 cases (1985-1994). J Am Vet Med Assoc 213: 1444-1448

Du YJ, Brash JL, McClung G, Berry LR, Klement P, Chan AK 2007: Protein adsorption on polyurethane catheters modified with a novel antithrombin-heparin covalent complex. J Biomed Mater Res A 80: 216-25

Falk T, Jonsson L 2000: Ischaemic heart disease in the dog: a review of 65 cases. J Small Anim Pract 41: 97-103

Forauer AR, Theoharis CG, Dasika NL 2006: Jugular vein catheter placement: histologic features and development of catheter-related (fibrin) sheaths in a swine model. Radiology 240: 427-34

Fox PR 1999: Feline cardiomyopathies: Arterial thromboembolism, in Fox PR, Sisson D, Moise NS (eds): Textbook of Canine and Feline Cardiology: Principles and Clinical Practice, ed 2. Philadelphia, WB Saunders, pp. 658-667

Goncavales R, Penderis J, Chang YP, Zoia A, Mosley J, Anderson TJ 2008: Clinical and neurological characteristics of aortic thromboembolism in dogs. J Small Anim Pract 49: 178-184

Hogan DF, Andrews DA, Green HW, Talbott KK, Ward MP, Calloway BM 2004: Antiplatelet effects and pharmacodynamics of clopidogrel in cats. J Am Vet Med Assoc 225: 1406-11

Jacoby RC, Owinngs JT, Ortega T, Gosselin R, Feldman EC 2001: Biochemical basis for the hypercoagulable state seen in Cushing syndrome; discussion 1006-7. Arch Surg 136: 1003-1006

Jaffe MH, Grooters AM, Partington BP, Camus AC, Gosgood G 1999: Extensive venous thrombosis and hindlimb edema associated with adrenocortical carcinoma in a dog. JAAHA 35: 306-310

Jandrey KE, Norris JW, MacDonald KA, Kittleson MD, Tablin 2008: Platelet function in clinically healthy cats and cats with hypertrophic cardiomyopathy: analysis using the Platelet Function Analyzer-100. Vet Clin Pathol 4: $385-388$

Johnson LR, Lappin MR, Baker DC 1999: Pulmonary thromboembolism in 29 dogs: 1985-1995. J Vet Intern Med 13: 338-345

Kagawa Y, Hirayama K, Uchida E, Izumisawa Y, Yamaguchi M, Kotani T, Niiyama M, Yoshino T, Taniyama H 1998: Systemic atherosclerosis in dogs: histopathological and immunohistochemical studies of atherosclerotic lesions. J Comp Pathol 118: 195-206

Killingsworth CR, Eyster GE, Adams T, Bartlett PC, Bell TG 1986: Streptokinase treatment of cats with experimentally induced aortic thrombosis. Am J Vet Res 47: 1351-9

Kittleson MD 1998: Thromboembolic disease, In: Kittleson MD and Kienle RD, eds. Small Animal Cardiovascular Medicine. St. Louis: Mosby, Inc. pp. 297-318

Klein MK, Dow SW, Rosychuk RA1989: Pulmonary thromboembolism associated with immune-mediated hemolytic anemia in dogs: Ten cases (1982-1987). JAVMA 195: 246-250

Konecny F 2008: A model of massive pulmonary embolism, development and characterization. The pre-clinical steps forward and details of the progress. JRMS 13: 121-134

Konecny F(a) 2008: Evaluation of Two Recombinant Plasminogen Activators in Massive Pulmonary Embolism Model and Potato Carboxypeptidase Inhibitor (PCI) Role in Inhibition of Thrombin Activatable Fibrinolysis Inhibitor TAFIa in Lungs. Recent Patents on Endocrine, Metabolic and Immune Drug Discovery 2: 45-56

Konecny F (a) 2006: Management of Pulmonary Embolism: the prophylaxis and therapy of DVT as prevention of massive pulmonary embolism (MPE), optimization of ventricular preload and the amplification of RV myocardial blood flow; and approach to life-threatening MPE. Chest Medicine Online (1-14): ISSN 1360-0168

Konecny F (b) 2007: Pulmonary Embolism and vascular injury: What role plays thrombin? JRMS 12: $203-216$

Konecny F (c) 2006: Massive pulmonary embolism: the predisposing and complicating factors, its current diagnostic approaches and critical importance of early diagnostic physical exam. JRMS 11: 406-414

Kristensen AT, Wiinberg B, Jenssen LR, Andeasen E, Jenssen AL 2008: Evaluation of human recombinant tissue factor-activated thromboelastography in 49 dogs with neoplasia. J Vet Intern Med 22: 140-7

LaRue MJ, Murtaugh RJ 1990: Pulmonary thromboembolism in dogs: 47 cases (1986-1987). JAVMA 197: $1368-1372$

Laste NJ, Hapster NK 1992: A retrospective study of 100 cases of feline aortic thromboembolism: 1977-1993. JAAHA 31: 492-500

Littman MP, Dambach DM,Vaden SL, Giger U 2000: Familial protein-losing enteropathy and protein-losing nephropathy in Soft Coated Wheaten Terriers: 222 cases (1983-1997). J Vet Intern Med 1: 68-80 
Liu S, Tilley LP, Tappe JP, Fox PR 1986: Clinical and pathologic findings in dogs with atherosclerosis: 21 cases (1970-1983). JAVMA 189: 227-232

Lunsford KV, Mackin AJ 2007: Thromboembolic therapies in dogs and cats: an evidence-based approach. Vet Clin North Am Small Anim Pract 37: 579-609

MacGregor JM, Rozanski EA, McCarthy RJ, Sharkey LC, Winter MD, Brown DJ, Rush JE 2004: Cholesterolbased pericardial effusion and aortic thromboembolism in a 9-year-old mixed-breed dog with hypothyroidism. J Vet Intern Med 18: 354-358

Malpother ED 1880: Phlebitis of the lower extremities: a secondary complication of injuries to the head. Br Med J p. 483

Maruyama H, Watari T, Miura T, Sakai M, Takahashi T, Koie H, Yamaya Y, Asano K, Edamura K, Sato T, Tanaka S, Hasegawa A, Tokuriki M 2005: Plasma thrombin-antithrombin complex concentrations in dogs with malignant tumours. Vet Rec 156: 839-840

Mcartney JS 1927: Pulmonary embolism: a report of seventy three cases. Arch Path 3: 921-937

McGuire NC, Vitsky A, Daly CM, Behr MJ 2002: Pulmonary thromboembolism associated with Blastomyces dermatitidis in a dog. J Am Anim Hosp Assoc 38: 425-430

Mesfin GM, Higgins MJ, Brown WP, Rosnick D 1988: Cardiovascular complications of chronic catheterization of the jugular vein in the dog. Vet Pathol 25: 492-502

Mitchell RN, Cotran RS 1999: Hemodynamic disorders, thrombosis, and shock, in Cotran RS, Kumar V, Collins T (eds): Robbins Pathologic Basis of Disease, ed 6. Philadelphia, WB Saunders pp. 113-138

Moore KE, Morris N, Dhupa N, Murtaugh RJ, Rush JE 2000: Retrospective study of streptokinase administration in 46 cats with arterial thromboembolism. J Vet Emerg Crit Care 10: 245-257

Morchon R, Rodriguez-Barbero A, Velasco S, Lopez-Belmonte J, Simon F 2008: Vascular endothelial cell activation by adult Dirofilaria immitis antigens. Parasitol Int 57: 441-6

Mupanomunda M, Williams JF, MacKenzie CD, Kaiser L 1997: Dirofilaria immitis: heartworm infection alters pulmonary artery endothelial cell behavior. J Appl Physiol 82: 389-98

Nichols R 1990: Concurrent illness and complications associated with canine hyperadrenocorticism. Probl Vet Med 4: 565-72

Norris CR, Griffey SM, Samii VF 1999: Pulmonary thromboembolism in cats: 29 cases (1987-1997). JAVMA 215: $1650-1654$

Owre A 1929: Studies of the clinic and etiology of post-operative thrombosis. Acta Chir Scand 65: 1-111

Palmer KG, King LG, van Winkle TJ 1998: Clinical manifestations and associated disease syndromes in dogs with cranial vena cava thrombosis: 17 cases (1989-1996). JAVMA 213: 220-224

Rawlings CA, Raynard JP, Lewis RE, Duncan JR 1993: Pulmonary thromboembolism and hypertension after thiacetarsamide vs melarsomine dihydrochloride treatment of Dirofilaria immitis infection in dogs. Am J Vet Res 54: 920-925

Rawlings CA, Keith JC Jr, Schaub RG 1985: Effect of acetylsalicylic acid on pulmonary arteriosclerosis induced by a one-year Dirofilaria immitis infection. Arterioscler Thromb Vasc Biol 5: 355-365

Rogers CL, O'Toole TE, Keating JH, Penninck DG, Webster CR 2008: Portal vein thrombosis in cats: 6 cases (2001-2006). J Vet Intern Med 22: 282-7

Santamarina G, Espino L, Vila M, Lopez M, Aleman N, Suarez ML 2003: Aortic thromboembolism and retroperitoneal hemorrhage associated with a pheochromocytoma in a dog. J Vet Intern Med 17: 917-922

Schaub RG, Rawlings CA, Keith JC Jr 1981: Platelet adhesion and myointimal proliferation in canine pulmonary arteries. Am J Pathol 104: 13-22

Schaub RG, Rawlings CA 1980: Pulmonary vascular response during phases of canine heartworm disease: Scanning electron microscopic study. Am J Vet Res 41: 1082-1089

Schermerhorn T, Pembleton-Corbett JR, Kornereich B 2004: Pulmonary thromboembolism in cats. J Vet Intern Med 18: 533-535

Schina MJ Jr, Neumyer MM, Healy DA, Atnip RG, Thiele BL 1993: Influence of age on venous physiologic parameters. J Vasc Surg $18: 749-752$

Schober KE, Maerz I 2006: Assessment of left atrial appendage flow velocity and its relation to spontaneous echocardiographic contrast in 89 cats with myocardial disease. J Vet Intern Med 20: 120-130

Seki Y, Machida N, Arimura T, Kiyu K, Kondoh M 1998: Transmural myocardial infarction caused by thromboembolism associated with mitral insufficiency in a dog. J Vet Med Sci 60: 741-743

Smith SA, Tobias AH, Jacob KA, Fine DM, Grumbles PL 2003: Arterial thromboembolism in cats: acute crisis in 127 cases (1992-2001) and long-term management with low-dose aspirin in 24 cases. J Vet Intern Med 17: $73-83$

Smith SA, Kraft SL, Lewis DC, Melethil S, Freeman 2000: Pharmacodynamics of warfarin in cats. J Vet Pharmacol Ther 23: 339-344

Sottiaux J, Franck M 1998: Cranial vena caval thrombosis secondary to invasive mediastinal lymphosarcoma in a cat. J Small Anim Pract 39: 352-355

Sottiaux J, Franck M 1999: Pulmonary embolism and cor pulmonale in a cat. J Small Anim Pract 40: 88-91

Stockol T, Brooks M, Rush JE, Rishniw M, Erb H, Rozanski E, Kraus MS, Gelzer AR 2008: Hypercoagulability in cats with cardiomyopathy. J Vet Intern Med 22: 546-552 
Thompson MF, Scott-Moncririef JC, Brooks MB 2004: Effect of a single plasma transfusion on thromboembolism in 13 dogs with primary immune-mediated hemolytic anemia. J Am Anim Hosp Assoc 40: 446-454

Thompson MF, Scott-Moncririef JC, Hogan DF 2001: Thrombolytic Therapy in Dogs and Cats. J Vet Emerg Crit Care 11: 111-121

Tsujino K, Hikasa Y, Minami S, Okamoto Y, Morita T, Shimada A: Chronic myocardial infarction due to arteriosclerosis of coronary arteries followed by acute thromboembolism of caudal abdominal aorta in a cat. $\mathrm{J}$ Vet Med Sci 67: 631-634

Van Winkle TJ, Bruce E 1993: Thrombosis of the portal vein in eleven dogs. Vet Pathol 30: 28-35

Van Winkle TJ, Hackner SG, Liu SM 1993: Clinical and pathological features of aortic thromboembolism in 36 dogs. J Vet Emerg Crit Care 3: 13-21

Ware AW, Fenner WR 1998: Arterial thromboembolic disease in a dog with blastomycosis localized in the hilar lymph node J Am Vet Med Assoc 193: 847-849

Wiinberg B, Jensen AL, Rozanski E, Johansson PI, Kjelgaard-Hansen M, Tranholm M,

Kristensen AT 2009: Tissue factor activated thromboelastography correlates to clinical signs of bleeding in dogs. Vet J 179: 121-129

Wright HP, Osborn SB 1952: Venous velocity in bedridden medical patients. Lancet 2: 699-700 